\title{
ANALYZING THE ETHNOCENTRIC BEHAVIOR OF CONSUMERS FOR FMCG PRODUCTS IN PUNE CITY
}

\author{
Harshada Raut \\ Assistant Professor, Department of Commerce, Savitribai Phule Pune University, \\ Maharashtra, India \\ Dr. Chhabi Sinha \\ Associate Professor, MITCOM- MIT College of Management, \\ MIT-ADT University, Pune, Maharashtra, India
}

\begin{abstract}
India witnessed an ace position in the world market in the good old days and was called as a golden sparrow. The unbritish rule led the poverty to India whereas its manufacturer status was changed to a market to the MNCs world over. The new economic policy was supportive to the aforesaid scenario. Conventionally, marketing too was production based where dumping the products was the main motto. But new era believes customer as a king. This emerged the need to understand the consumer psychology. The consumer behavior is dependent upon numerous variables which range from the psychological, economic, social political aspects. Indian consumer has also changed over the years initially he was ethnic, then he was forced to buy the foreign products, then he had witness the Brand wars and now the last two decades Indian consumer has been deliberately choosing the domestic products over the foreign ones owing to the indigenous options that are available in the market meeting his requirements. This urges the researcher to once again check the ethnocentric tendencies of the Indian consumer.
\end{abstract}

Key words: Consumer, Ethnocentric, Behavior, Indigenous

Cite this Article: Harshada Raut and Dr. Chhabi Sinha, Analyzing the Ethnocentric Behavior of Consumers for FMCG Products in Pune City, International Journal of Management, 11(12), 2020, pp 1128-1137.

http://iaeme.com/Home/issue/IJM?Volume=11\&Issue=12

\section{INTRODUCTION}

Ethnocentricity or ethnocentrism is that the inclination to gauge or analyze the world from the angle of one's own culture. Within that given set, the ethnocentrism directs to an increase in cluster conformity and faithfulness quality and conjointly depends immensely on the kind of 
such social grouping, pride, chauvinism and ethnic discrimination. The construct 'ethnocentrism' was 1st applied within the field of social science by William Graham Sumner, a sociologist, in 1906. He elucidated the ethnocentrism as "the one's own alliance that's core of the entire factor, to gauge rest all teams against". The construct was originated from the discipline of social science and also the sub-discipline of social anthropology. The term 'ethnocentrism' has its pedigree in social science. It symbolizes the universal tendency for individuals to look at their own cluster as the center of the universe and to snub those who square measure culturally totally different whereas blindly acceptive for those that square measure culturally similar (Shimp and Sharma 1987). Ethnocentrism includes two integral sides i.e. perspective and behavior. Ethnocentric shoppers are of the perspective that their own teams square measure prevailing than others. (Poturak, 2013). Relating to consumer behavior, they like domestic over foreign products'. The fondness of domestic merchandise is because of the love for his or her country and also the worry of foreign merchandise dominating the market. Regardless of the knowledge about superiority of overseas products, ethnocentric customers sightlessly prefer to use domestic products (Shimp and Sharma 1987). In order to support his/her own culture, the ethnocentric consumer eventually still bear crisis (Cleveland, Laroche, and Papadopoulos 2009).

A) Conservatism: Conservatism is that the tendency to take care of and preservation of the standard order of the society that has endured the tests of the time. It's outlined as "a tendency to hold dear traditions and social establishments that have survived the over a period of testing times and to approve changes solely sometimes, that too gradually and reluctantly" Sharma et al. Furthermore they contended that ideology of conservatism will present itself as insistence of strict rules and punishments, non secular outlook and also an anti-hedonic outlook in its extreme appearance. The result of studies is differing with regard to developing and developed nations. Wang contended that this ideology of conservatism attribute and favorable perspective towards international brands has negative relationship in developed countries. However, Sharma et al. and Balabanis et al. notice that ideology of shoppers is completely related to the CET.

B) Patriotism: A number of researchers have outlined it from completely different views, like "a love of national symbols", devotion to one's own country and commitments of individuals towards their mother nations, "sense of national loyalty". Schatz et al. asserts the patriotism is nothing but a strong feeling of attachment for his / her country which can be exemplified by intolerance of criticism, obedient optimistic evaluation and staunch commitment". The correlation between CET and loyalty towards the country supported by numerous studies like Han, Sharma et al. , Klein and Ettenson, Balabanis and Adamantios

C) Ethnicity: Baumann measures ethnicity as a derivative of social anthropology. Siemieniako et al. (2011) recognized it as a sociopsychological antecedent .Vida et al considers ethnicity as the quality as robust predictor of CET.

D) Xenophobia: Xenophobia is outlined as the "negative perspective toward, or fear of, people or teams of people that are in some sense completely dissimilar (real or imagined) from oneself or the group(s) to that one belongs" by Hjerm. Fear of global brands Altintas and Tokol. Further, they could establish with their experimental support, a robust positive linking between Xenophobia and the consumer ethnocentrism Siemieniako et al.

E) Collectivism: It's the socio-psychological idea and is outlined as the social orientation in terms of non-public traits of people to examine collective goals instead of individual goals. Collectivism could be a major component of individual cultural orientation. Furthermore folks grading high on collectivism tend to reveal a lot of intensive ethnocentric inclination against individualistic goals 
CETSCALE: (Consumer Ethnocentric Tendencies Scale) is devised by Shimp and Sharma (1987). In order to measures ethnocentric behavior of the consumers. This measuring tool involves a complete of seventeen traits. It basically assess consumers to differentiate between foreign products and home country products strictly on the nationalist reasons regardless of class, superiority, and cost or desired features. CET isn't a particular perspective however the aggregation of general tendencies towards 'in-group love'. It's bigger tendency of physical property with regard to alternative merchandise or worth tags. it's a results of perceived concern of people for his or her own country as critical negative effects of imports for nation particularly plight of their citizen with regards to unemployment.

\section{LITERATURE REVIEW}

Developed countries such as USA and Canada discovered that consumers in general incline to have a more positive feature perception of national than foreign products (Bilkey and Nes 1982; Dickerson 1982; Samiee 1994; Ahmed and d'Astous 2001). Moreover, ethnocentric consumers in well-developed countries cogitate it their responsibility to purchase domestic products so as to upturn commerce and lift economy in their country (Shimp and Sharma 1987; Vida and Fairhurst 1999).In China, trials and attitudinal analyses in a field setting were directed using CET scale to scrutinize the obstacles for internationalizing the acceptance to brand and luxury products in the native against foreign markets. National products do not survive the demand of luxury that stimulates consumers to purchase foreign products $(\mathrm{Bi}$, Gunessee et al. 2012. Bosnia and Herzegovina exhibited that there was a sure level of ethnocentrism among the Bosnian and Herzegovinian consumers (Poturak, 2013). But, among the Ghanaian buyers, the ethnocentrism was slight due to their cultural variety and intercultural compassion about the way they converse. The Ghanaian civilization has been different and are chiefly more open minded. Furthermore, their inclination for local goods did succeed but to a minor extent (Mensah, Bahhouth \& Ziemnowicz, 2011). The evaluation was done among consumers of New Zealand, US, Germany, Italy, and Singapore. B. Zafer Erdogan Cevahir Uzkurt(2010) had used CETSCALE to size ethnocentric behavior of Consumers in Turkey and had determined that consumers with minor levels of ethnocentrism notice foreign-made products to be more promising than their corresponding item who have higher levels of ethnocentricity. Consumer ethnocentrism amid Australian consumers had a considerably negative consequence on purchase purposes for products from developing countries. Consumer's ethnocentric inclination positively related to meaning to purchase indigenous products and undesirably related to products from former Yugoslavia and European Union. Ethnocentricity is definitely related to customers' purchase target towards goods manufactured domestically which was accurate among North Cyprus consumers as calculated by Nadiri \& Tümer (2010). The influence of patriotism and nationalism is not constant across Turkey and Czech Republic. It is evident that patriotism is the main driving force behind consumer ethnocentrism in Turkey whereas in the Czech Republic it is nationalism. Internationalism has no noteworthy effect on consumer ethnocentrism. (Balabanis et al).

If we study, in India the demographic exploration displayed that age and educational qualification exaggerated ethnocentrism among Indian consumers. The youth of India favor more of national products over imported products and had advanced ethnocentric tendencies (Srivastava, 2013).Indian consumers' ethnocentric affinities are biased by the demographic variables such as earning levels, educational qualification, as well as cultural openness, and kind of being collectivist. Ethnocentrism of Indian consumers fortunate trust about foreign product go hand in hand was further confirmed by Swati Kewlani(2013). Archana Kumar, Ann Fairhurst \& Youn-Kyung Kim(2011) had studied that Indian consumers who are ethnocentric were found to have inclination towards domestic products vs foreign products 
The analyses of the study showed that women are more ethnocentric than men. But, there was no weighty relationship between ethnocentrism, age, income, and educational levels (Mangnale, Potluri \& Degufu, 2011). In India, the tag 'made in India' is not a liability. The Indian consumers will not circle up foreign goods simply because of their 'made in' tags. That the young Indians (a numerically very large segment of the market) are the furthermost consumer ethnocentric of them all points to an easy future for the 'made in India' label. (Anupam Bawa 2010). Archana Kumar, Ann Fairhurst \& Youn-Kyung Kim (2011) suggest that Indian consumers who are ethnocentric favor national product/service to foreign product/service. Ethnocentrism of Indian consumers is influenced by education, income, cultural openness, and collectivism...Patriotism' and 'product features' came up as significant for purchase intention of Indian customer. (David Campbell 2017)

Virtually studies have established mixed results on the cogency and uni-dimensionality of the CETSCALE (Netemeyer et al., 1991; Durvasula et al., 1997; Witkowski, 1998; Saffu\& Walker, 2005). Empirical studies have shown the character of the merchandise influencing the patron partisanship, like level of product involvement, perceived product necessity, and therefore the extent to that the foreign-made product may be a threat to non-public or national welfare (Herche, 1992; Kaynak \& Cavusgil, as cited in Lindquist et al., 2001). Whereas, studies by Lindquist, Vida, Plank, and Fairhurst (2001) and Saffu and Walker (2005) have come upon the match results acceptable even supposing in later studies uni-dimensionality was found to be valid for Canada however not for Russia. Studies by Bawa (2004) on Republic of India, Teo et al. (2011) on Malaya, and The Little Giant and Nijsen (2002) on Holland originate the CETSCALE to be dimensional. A study by Saffu and Walker (2006) on Republic of Ghana found the 17-items dependable however not unidimensional. Netemeyer et al. (1991) originateed sturdy support for the CETSCALE issue structure and reliableness across the four countries in his study. Previous analysis (Shimp and Sharma, 1987; Netemeyer et. al., 1991) documented uni-dimensionality along with issue assembly unalterable and discriminate, validness of the CETSCALE and trustworthiness across the borders of nations (Sharma et al. 1995; smart and Huddleston, 1995; Nielsen and Spence, 1997; Suh et al, 2002; Javalgi et al, 2004; Reardon et al, 2005;Hamin and Elliott, 2006; Chryssochoidis et al, 2007; Liu et al, 2007)

Even though the concept of consumer ethnocentrism is studied quite well in the literature, lacking of consumer ethnocentrism in cultures of Indian society is still evident. The objective of this study is to examine consumer ethnocentrism in Indian societies and further to reveal whether more ethnocentric consumers would have higher preferences of domestic manufactured products. Since consumer ethnocentrism is a more powerful influence on consumer preferences for domestic and foreign products than demographic or marketing-mix variables (Herche, 1994), its understanding is vital for international marketers

\section{OBJECTIVES}

- What is Consumer Ethnocentrism

- How to measure consumer ethnocentrism

- Analyze the consumer behavior for FMCG products.

\section{RESEARCH METHODOLOGY}

Research Instrument: This study employs the 17-item CETSCALE advanced by Shimp and Sharma (1987) and utilized by earlier researchers (Good and Huddleston, 1995; Netemeyer et al., 1991; Herche, 1994; Shimp and Sharma, 1995; Durvasula et al., 1997; Luque-Martinez et al., 2000). The CETSCALE measures consumer ethnocentrism using a Likert-type scale $(1=$ Strongly Disagree to $5=$ Strongly Agree). Consumers were asked to streak their response for 
the Indian and Non-Indian products. The consumers were to respond for soap, Tea, Biscuits, tooth paste, fabric wash.The 17 item CETSCALE was tested for 225 samples. Subsequently, items that seemed problematic were reworded and refined (Malhotra, 1991).

The Sample: The sample comprised consisted of the citizens from the Pune city. These samples were from various areas of Pune city and were randomly collected. Consequently, the population in this sample is cosmopolitan and culturally diverse as well as being socioeconomically diverse, it is expected that such diversity will generate varied perspectives, and will, thereby, enrich the findings of the study. The questionnaire was administered in the presence of the authors so that doubts, if any, could be addressed.

Rescore: CETSCALE scores were calculated for each respondent, with the mean, the standard deviation of the. The CETSCALE demands along with the mean and standard deviation for each question are presented in Table. The mean ethnocentrism value directs the intensity of ethnocentrism (Shimp et al., 1987). An advanced mean value specifies advanced consumer ethnocentrism, while inferior mean value implies lesser ethnocentrism. On the contrary the higher the CETSCALE mean value the more ethnocentric the group under investigation, and the lower the mean value, the less ethnocentric the group that is being investigated. They can best be described as moderately ethnocentric since the mean score is in the middle of the range of the CETSCALE Score (17 to 85).

Reliability: Succeeding previous research (Shimp and Sharma, 1987; Netemeyer et al., 1991; Sharma et al. 1995; Muyle et al., 1997; Hult et al., 1999), the CETSCALE's reliability was measured using Cronbach's alpha (Fornell and Larcker, 1981). The Cronbach alpha was 0.913, which indicates that the CETSCALE score is reliable for the Indian data since it exceeds the rule-of-thumb value of 0.70 (Nunnally, 1978; Hatcher, 1994). So it can be clinched that the CETSCALE is reliable across the Indian sample (Fornell and Larcker, 1981).

Table 1

\begin{tabular}{|c|l|}
\hline S.no & \multicolumn{1}{|c|}{ Statements } \\
\hline 1. & Indian people should always buy Indian made products. \\
\hline 2. & Only those products that are unavailable in India should be imported \\
\hline 3. & Buy Indian made products. Keep India working? \\
\hline 4. & Indian products first, last and foremost. \\
\hline 5. & Purchasing foreign made products is un-Indian. \\
\hline 6. & It is not right to purchase foreign products because it puts Indian out of jobs. \\
\hline 7. & A real Indian should always buy India-made products. \\
\hline 8. & We should purchase products manufactured in India instead of letting other people get rich off us. \\
\hline 9. & It is always best to purchase Indian products. \\
\hline 10. & $\begin{array}{l}\text { There should be very little trading or purchasing of products from other countries unless out of } \\
\text { necessity. }\end{array}$ \\
\hline 11. & Indians should not buy foreign products because it hurts Indian business and causes unemployment. \\
\hline 12. & Curbs should be put on all imports of products. \\
\hline 13. & It may cost me in the long run but I prefer to support India made products \\
\hline 14. & We should obtain from foreign countries only those products that we cannot obtain within our country. \\
\hline 15. & Foreigners should not be allowed to put their products on our markets. \\
\hline 16. & Foreign products should be taxed heavily to reduce their entry into India. \\
\hline 17. & $\begin{array}{l}\text { Indian consumers who purchase products made in other countries are responsible for putting their } \\
\text { fellow Indians out of work. }\end{array}$ \\
\hline
\end{tabular}

Out of the above statements following groups were made for hypothesis testing 
Table 2

\begin{tabular}{|c|c|c|}
\hline $\begin{array}{c}\text { Sr.N } \\
\text { o }\end{array}$ & $\begin{array}{l}\text { Independent } \\
\text { Variables }\end{array}$ & Statements \\
\hline 1. & Patriotism & $\begin{array}{l}\text { Indian people should always buy Indian -made products instead of imported. } \\
\text { Indian products first last and foremost. } \\
\text { A real Indian should always buy Indian -Made products. } \\
\text { It is always best to purchase Indian made products. }\end{array}$ \\
\hline 2. & Collectivism & $\begin{array}{l}\text { 1)We should always purchase the products manufactured in India instead of letting } \\
\text { other countries getting rich of us } \\
\text { 2) There should be very little purchasing of goods from the other countries unless out } \\
\text { of necessity. } \\
\text { 3) It may cost me in the long run but I prefer to support Indian Products. } \\
\text { 4) We should obtain from foreign countries only those products we cannot obtain in } \\
\text { our country. }\end{array}$ \\
\hline 3. & Ethnicity & $\begin{array}{l}\text { 1) Since these products are made by the Indian Manufacturers they understand the } \\
\text { Indian consumer more than the foreign companies. } \\
\text { 2) The brands that I use show some national identity (like usage of ayurvedic herbs } \\
\text { (neem, babul, and clove) in tooth paste etc. Which makes me prefer the product. }\end{array}$ \\
\hline 4. & $\begin{array}{l}\text { Conservatis } \\
\mathrm{m}\end{array}$ & $\begin{array}{l}\text { 1) Only those products unavailable in India should be imported. } \\
\text { 2) Foreign Products should be taxed heavily to reduce their entry to India }\end{array}$ \\
\hline 5. & Xenophobia & $\begin{array}{l}\text { 1)Purchasing foreign products is anti-national } \\
\text { 2)Curbs should be put on all imports }\end{array}$ \\
\hline
\end{tabular}

\section{FINDINGS AND CONCLUSION}

Dimensionality: we used chisquare test to test the independent and the dependent variables and the relationship between them. Patriotism, Xenophobia, Collectivism, conservatism and Ethnicity are the independent variables and ethnocentrism is the dependent variable. Further the ethnocentric tendencies and the actual purchases has been tested

Table 3

\begin{tabular}{|l|l|c|c|c|}
\hline Sr.No & \multicolumn{1}{|c|}{$\begin{array}{c}\text { Independent } \\
\text { Variables }\end{array}$} & X2 & df & $\begin{array}{c}\text { P- } \\
\text { Value }\end{array}$ \\
\hline 1. & Patriotism & 21.434 & 1 & 0.000 \\
\hline 2. & collectivism & 9.007 & 1 & .003 \\
\hline 3. & Ethnicity & 8.563 & 1 & .003 \\
\hline 4. & Conservatism & 4.391 & 1 & .036 \\
\hline 5. & Xenophobia & 2.996 & 1 & .083 \\
\hline
\end{tabular}

Table 4

\begin{tabular}{|c|l|c|c|}
\hline Sr.No & $\begin{array}{c}\text { Elements of } \\
\text { Ethnocentrism }\end{array}$ & $\begin{array}{c}\text { Swadeshi } \\
\text { Brands are } \\
\text { Better }\end{array}$ & $\begin{array}{c}\text { Swadeshi Brands are not } \\
\text { good }\end{array}$ \\
\hline 1. & Patriotism & $91.9 \%$ & $8.1 \%$ \\
\hline 2. & Collectivism & $89.8 \%$ & $10.2 \%$ \\
\hline 3. & Ethnicity & $90.2 \%$ & $9.8 \%$ \\
\hline 4. & Conservatism & $91.9 \%$ & $8.1 \%$ \\
\hline 5. & Xenophobia & $90.2 \%$ & $9.8 \%$ \\
\hline
\end{tabular}




\section{DISCUSSIONS}

In this study, our motive was to study the ethnocentric tendencies in customers in Pune city regarding the FMCG products. Certain class of products like soap, tea, were provided and also the Indian and non-Indian brands were asked to be chosen by the customers. The findings approve results from previous analysis (Sharma et al., 1995; Ruyter et al., 1998). The study demonstrates that CETSCALE behaves even as a scale ought to behave in terms of reliableness. A significant finding of this study and aid to the literature, is that the multidimensionality of the CETSCALE. Former analysis (Shimp and Sharma, 1991; Netemeyer et al., 1991; Herche, 1992; Sharma et al., 1995; Durvasula et al., 1997) establish the CETSCALE to be uni-dimensional. World marketers about to endorse and sell foreign merchandise ought to think about demographics, socio-psychological variables, and consumers' opinions of alternative nations' orientation whereas developing their ways. In India, the first CETSCALE performs as a scale to judge the judgement of customers on shopping for foreign-made merchandise. This argument is even as eight out of seventeen things of the CETSCALE were found to be applicable for Asian country with high reliableness and validity values (even although not unidimensional).

\section{REFERENCES}

[1] Ahmed, S.A., and A. d'Astous. 2001. Canadian consumers' perceptions of products made in newly industrializing East Asian countries. International Journal of Commerce and Management 11, no. 1: 54-72.

[2] Anupama Bawa(2004)VIKALPA Consumer Ethnocentrism CETSCALE Validation and Measurement of Extent Volume 29 No 3 July - September 43

[3] Balabanis, G., Diamantopoulos, A., 2004. Domestic country bias, country-of-origin effects, and consumer ethnocentrism: a multi- dimensional unfolding approach. Academy of Marketing Science 32, 80-95.

[4] Balabanis, g., Diamantopoulos, A., Mueller, R., Melewar, T., 2001. The impact of nationalism, patriotism and internationalism on consumer ethnocentric tendencies. Journal of International Business Studies 32, 157-175.

[5] Bandyopadhay, S., Saevarsdottir, K., 2001. Ethnocentrism in Icelandic consumers and its impact on the evaluation of imported products. In: International Business Track. Decision Sciences Institute Annual Meeting, San Francisco, CA.

[6] Bandyopadhyay, S., 2012. Ethnocentrism in Icelandic consumers and its consequences. International Business and Economics Research Journal 11, 307-314.

[7] Batra, R., V. Ramaswamy, D.L. Alden, J.-B.E.M. Steenkamp, and S. Ramachander. 2000Effects of brand local and nonlocal origin on consumer attitudes in developing countries.Journal of Consumer Psychology 9: 83-95.

[8] Baumann Z (2004) Identity Cambridge: Polity Press. In: Callender CO, Miles PV editors. Obstacles to organ donation in ethnic minorities. Paediatr Transpl 5: 383-385.

[9] Bawa, A., 2004. Consumer ethnocentrism: CETSCALE validation and measurement of extent. Vikalpa 29, 43-57.

[10] Bhuian, S., (1997). "Saudi Consumers' Attitudes towards European, US and Japanese Products and Marketing Practices", European Journal of Marketing, 3(7): 467-86.

[11] Bilkey, W., and Nes, E (1982). "Country-of-Origin Effects on Product Evaluations," Journal of International Business Research, 13: 89-99.

[12] Booth, K. 1979. Strategy and ethnocentrism. London: Croom-Helm.brand goods. Manage Decis 51: 434-450. 
[13] Cleveland, M., M. Laroche, and N. Papadopoulos. 2009. Cosmopolitanism, consumer ethnocentrism, and materialism: an eight-country study of antecedents and outcomes. Journal of International Marketing 17, no. 1: 116-46.

[14] Dickman, S.J. (2000). Impulsivity, arousal and attention. Personality and Individual Differences, 28 (5), pp.

[15] Durvasula, S., Andrews, J. and Netemeyer, R., (1997). "A Cross-Cultural Comparison of Consumer Ethnocentrism in the United States and Russia", Journal of International Consumer Marketing, 9(4): 73-93.

[16] Durvasula, S., Andrews, J. and Netemeyer, R., (1997). "A Cross-Cultural Comparison of Consumer Ethnocentrism in the United States and Russia", Journal of International Consumer Marketing, 9(4): 73-93.

[17] Elliott, G., and Cameron, R., (1994). 'Consumer Perception of Product Quality and the Country-of-Origin Effect’ Journal of International Marketing, 2(2): 49-62.

[18] Fornell, C. and Larcker, D. (1981), "Evaluating Structural Equation Models with Unobservable Variables and Measurement Error," Journal of Marketing Research, 18 (February), 39-50.

[19] George Balabanis; Adamantios Diamantopoulos; Rene Dentiste Mueller; T C Melewar (2001) The impact of nationalism, patriotism and internationalism on consumer ethnocentrism.. Journal of International Business Studies; First Quarter; 32, 1;ABI/INFORM Research pg. 157

[20] George Chryssochoidis, Athanassios Krystallis, Panagiotis Perreas, (2007) "Ethnocentric beliefs and country-of-origin (COO) effect: Impact of country, product and product attributes on Greek consumers' evaluation of food products", European Journal of Marketing, Vol. 41 Issue: $11 / 12$, pp.1518- 1544, https://doi.org/10.1108/03090560710821288

[21] Good, L., and Huddleston, P., (1995). "Ethnocentrism of Polish and Russian Consumers: Are Feelings and Intentions Related?", International Marketing Review, 12(5): 35-48.

[22] Han CM (1988) The role of consumer patriotism in the choice of domestic versus foreign products. J Advertising Res, pp: 25-32.

[23] Han, C and Terpstra, V., (1988). "Country-of-Origin Effects for Uni-National and Bi- National Products,” Journal of International Business Studies, 16 (Summer): 235-56.

[24] Han, C., (1989). “Country Image: Halo or Summary Construct?” Journal of Marketing Research, 26, May: 222-9.

[25] Hatcher, L., (1994). A Step-by-Step Approach to Using the SAS System for Factor Analysis and Structural Equation Modelling, SAS Institute Inc., Cary, NJ, USA.

[26] Herche, J (1990) "The measurement of Consumer Ethnocentrism: Revisiting the CETSCALE" in Developments in Marketing Science, Dunlop, J and Cullowhee (editors), Academy of Marketing Science, 23: 37-375.

[27] Herche, J (1992) "A Note on the Predictive Validity of the CETSCALE", Journal of the Academy of Marketing Science, 20: 261-264.

[28] Herche, J., (1994). "Ethnocentric Tendencies, Marketing Strategy and Import Purchase Behaviour", International Marketing Review, 11(3): 4-16.

[29] Heslop, L., Papadopoulos, N., and Bourke, M., (1998). "An Interregional and Intercultural Perspective on Subculture Differences in Product Evaluation", Canadian Journal of Administrative Sciences, 15(2): 113-127.

[30] Huddleston P, Good LK, Stoel L (2001) Consumer ethnocentrism, product necessity and Polish consumers' perceptions of quality. Int J Retail Distrib Manage 29: 236-246

[31] Hult, G., Keillor, B., and Lafferty, B. (1999). "A Cross-National Assessment of Social Desirability Bias and Consumer Ethnocentrism”, Journal of Global Marketing, 12(4): 29-43. 
[32] Hult, G., Keillor, B., and Lafferty, B. (1999). "ACross-National Assessment of Social Desirability Bias and Consumer Ethnocentrism”, Journal of Global Marketing, 12(4): 29-43.

[33] Javalgi RG, Scherer RF (2005) An Application of the Consumer Ethnocentrism Model to French Consumers. Int Bus Rev 14: 325-344.

[34] Kaynak, E. and Cavusgil, S.T., (1983). "Consumer Attitudes towards Products of Foreign Origin: Do They Vary across Product Classes?", International Journal of Advertising, 2: 147157.

[35] Kaynak, E., and Kara, A., (1996). "Ethnocentric Behaviour of Consumers in Emerging Market Economy", AMA Winter Educators' Conference: Marketing Theory and Applications, 7: 3945.

[36] Kaynak, E., and Kara, A., (2002). "Consumer Perceptions of Foreign Products: An Analysis of Product-country Images and Ethnocentrism”, European Journal of Marketing, 36(7/8): 928949.

[37] Kaynak, E., and Kara, A., (2002). "Consumer Perceptions of Foreign Products: An Analysis of Product-country Images and Ethnocentrism”, European Journal of Marketing, 36(7/8): 928949.

[38] Kinra, N. 2006. The effect of country-of-origin on foreign brand names in the Indian market. Marketing Intelligence and Planning 24, no. 1: 15-30.

[39] Klein, J., Ettenson, R., and Morris, M., (1998). "The Animosity Model of Foreign Product Purchase: An Empirical Test in the Peoples' Republic of China”, Journal of Marketing, 62, pp. 89-100.

[40] Klein, J., Ettenson, R., and Morris, M., (1998). "The Animosity Model of Foreign Product Purchase: An Empirical Test in the Peoples' Republic of China", Journal of Marketing, 62: 89100.

[41] Kumar A, Fairhurst A, Kim Y (2011) Ethnocentric tendencies of Indian consumers: impact on preference for domestic versus foreign products. Int Rev Retail, Distrib Consum Res 21: 323341.

[42] Luque-Martinez, T., Ibanez-Sapata, J., and del Barrio-Garcia, S., (2000). "Consumer Ethnocentrism Measurement: An Assessment of the Reliability and Validity of the CETSCALE in Spain”, European Journal of Marketing, 34(11/12): 1353-1373.

[43] Marcoux, J.-S., Filiatrault, P., and Chéron, E., (1997). "The Attitudes Underlying Preferences of Young Urban Educated Polish Consumers Towards Products Made in Western Countries", Journal of International Consumer Marketing, 9(4): 5-29.

[44] Mulye, R., Rickard, J., and Higginson, T., (1997). "Some Evidence of Consumer Ethnocentrism in Australia", Journal of the Australian and New Zealand Academy of Management, 3(2): 1-11.

[45] Netemeyer, M., Durvasula, S., and Lichtenstein, D., (1991). "A Cross-National Assessment of the Reliability and Validity of the CETSCALE," Journal of Marketing Research, 28 (August): $320-7$.

[46] Nunnally, J., (1978). Psychometric Theory, 2nd ed., McGraw-Hill, New York, NY, USA.

[47] Papadopoulos, N., and Heslop, L., (1993). Product-Country Images: Impact and Role in International Marketing, International Business Press, New York, NY, USA.

[48] Papadopoulos, N., Heslop, F. Graby and G. Aavlonitis (1987), "Does 'Country of Origin' Matter? Some Findings from a Cross Cultural Study of Consumer Views about Foreign Products", Marketing Science Institute, Cambridg, MA, USA. 
[49] Papadopoulos, N., Heslop, L., Graby, F., and Aavlonitis, G., (1989), "Does 'Country of Origin' Matter? Some Findings from a Cross Cultural Study of Consumer Views about Foreign Products", Marketing Science Institute, Cambridge: MA.

[50] Papadopoulos, N., Heslop, L.A., Bamossy, G. (1991) A comparative image analysis of domestic versus imported products, International Journal of Research in Marketing, 7 (4), 283294

[51] Poturak, M. (2013). Role of Ethnocentrism and its Effect on Purchase Decisions. CEA Journal of Economics, 8(1).

[52] Samiee, S., (1994). "Customer Evaluation of Products in a Global Market", Journal of International Business Studies, 25(3): 579-604.

[53] Schatz R, Staub E, Lavine H (1999) On the Varieties of National Attachment: Blind versus Constructive Patriotism. Polit Psychol 20: 151-174.

[54] Sharma S, Shimp TA, Shin J (1995) Consumer Ethnocentrism: A Test of Antecedents and Moderators. J Acad Market Sci 23: 26-37.

[55] Sharma, S., Shimp, T., and Shin, J., (1995) 'Consumer Ethnocentrism: A Test Antecedents and Moderators' Journal of the Academy of Marketing Science, 23(1): 26-37.

[56] Sharma, S., Shimp, T., and Shin, J., (1995). "Consumer Ethnocentrism: A Test Antecedents andModerators," Journal of the Academy of Marketing Science, 23(1): 26-37.

[57] Shimp, T., and Sharma, S., (1987). "Consumer Ethnocentrism: Construction and Validation of the CETSCALE”, Journal of Marketing Research, 23: 280-289.

[58] Siemieniako D, Kubacki K, Glinska E, Krot K (2011) National and regional ethnocentrism: a case study of beer consumers in Poland. Brit Food J 113:404-418.

[59] Vida I, Dmitrovic T, Obadia C (2008) The role of ethnic affiliation in consumer ethnocentrism. Eur J Market 42: 327-343.

[60] Wang, C., and Lamb, C., (1983). "The Impact of Selected Environmental Forces upon Consumers' Willingness to Buy Foreign Products", Journal of the Academy of Marketing Science, 11(2): 71-84

[61] Watson, J., and Wright, K., (2000). "Consumer Ethnocentrism and Attitudes toward Domestic and Foreign Products", European Journal of Marketing, 34(9/10): 1149-1166. 